\title{
INDONESIAN MUSLIMS' DISCOURSE OF HUSBAND-WIFE RELATIONSHIP
}

\section{Nina Nurmila}

The Faculty of Tarbiyah and Education, State Islamic University (UIN) Sunan Gunung Djati, Bandung, Indonesia

\section{Abstract}

Islam as the majority religion in Indonesia has important infuence on its adherents, including in the metter of husband-wife relationship. This paper aims at discussing Indonesian Muslims' discourse of husband-wife relationship. In Indonesia, Muslim women are mainly accustomed to stay at home, to respect and to obey their husbands. This construction of women's domestication and subordination is usually based on the two most frequently quoted hadiths: (1) on the curse of angel for women who refuse to have sex with their husband; and (2) on the woman whose parent enters paradise because of the woman's obedience to her husband. The two traditions are commonly used to justify this construction of busband-wife relationship. However, since the coming influence of global Muslim feminism in Indonesia in the early 1990s, this traditional construction of husband-wife relationship has been criticized by the emerging Indonesian Muslim feminist scholars whose works have provided new perspective on the discourse of husband-wife relationship. Different from the mainstream perspective which tends to domesticate and subordinate women, the new perspective gives position to women and should be treated as equal partner of their husband.

Islam sebagai agama mayoritas di Indonesia berpengarub besar dalam keseluruban aspek. kehidupan pemeluknya, tidak terkecuali dalam aspek. bubungan suami-istri. Artikel ini mendiskusikan diskursus relasi suami-istri yang dilontarkan oleh pemikir Islam di Indonesia. Di Indonesia, perempuan 
Muslim kerap ditempatkan dalam ranah domestik saja, dituntut untuk menghormati dan mematuhi suami mereka. Carapandang domestifikasi dan subordinasi perempuan tersebut biasanya didasarkan pada hadith mengenai murka para malaikat kepada perempuan yang menolak ajakan berbubungan badan para suami dan hadith yang menceritakan kisah orang tua seorang istri yang tunduk terbadap perintah suaminnya. Namun, sejak dekade 1990 an, ketika feminisme global diperkenalkan, konstruksi tersebut dikritik oleh sebagian kalangan akadimisi feminist Muslim, yang karya-karyanya mengetengabkan perspektif baru mengenai diskursus hubungan suami-istri. Berbeda dengan perspektif mainstream, perspektif baru ini menempatkan perempuan pada posisi yang sejajar dengan suami mereka.]

Keywords: asymmetrical relationship, domestication, subordination, equal partnership.

DOI: 10.14421 /ajis.2013.511.61-79

\section{A. Introduction}

The discourse of the relationship between husband and wife among Indonesian Muslims is heavily influenced by their interpretation of religious texts, mainly the Qur'an and hadith. Based on their interpretation of these texts, Muslim man is instructed to be leader of the family, while Muslim woman should stay at home, to respect and obey their husband. This construction, however, has been challenged by some Muslim feminists who argue over equal partnership between husband and wife. This article discusses Indonesian Muslims' discourse of husband-wife relationship by firstly elaborating the existing construction of husbandwife relationship, which is the living interpretation of the Qur'an and hadith circulated among Indonesian Muslims; and secondly by explaining Muslim feminists' challenge to this existing construction. These Muslim feminists provide other alternative interpretation to the Qur'anic verses and hadiths which have been mainly used to justify women's subordination and domestication, offering the idea of equal partnership between husband and wife. 


\section{B. Religious Construction of Husband-Wife's Relationship}

This part of the paper explains some examples of religious construction of husband-wife relationship. First, Indonesian Muslim man has been religiously constructed to be leader of the family, while Muslim women should be house wife. Second, Indonesian Muslim woman has been commanded to fulfill the sexual needs of their husband whenever and wherever the husband desires it. Third, Indonesian Muslim women has been constructed to obey their husband. Fourth, Indonesian Muslim woman has been ordered to be submissive and respectful to her husband.

\section{The Religious Construction that Men are Leader of the Family}

The religious construction that man should be leader of the family is mainly based on Muslim literal understanding of the Qur'an Verse anNisa' (4): 34, "Men are leaders of women, because Allah has given some of them (men) superiority than the other (women), and because they (men) support them from their means. Therefore the righteous women are devoutly obedient, and guard in (the husband's) absence what Allah would have them guard. As to those women on whose part you fear disloyalty and ill-conduct (Nusyü), admonish them (first), (next), refuse to share their beds, (and last) beat them; but if they return to obedience, seek not against them means (of annoyance)." ${ }^{1}$ The verse is mostly interpreted as that men are naturally leaders of women, born superior to women, and they therefore should economically support women. ${ }^{2}$ This religious interpretation has been further emphasised in the 1974 Marriage Law Article 31 (3) which states that "a husband is the family leader and the wife is a house wife [suami adalah kepala keluarga dan isteri adalah ibu rumah tangga]."

${ }^{1}$ My translation with some reference to Abdullah Yusuf Ali's translation and the translation of the Ministry of Religious Affairs (MORA), see Abdullah Yusuf Ali, The Meanings Of The Holy Qur'an, http://www.islam101.com/quran/yusufAli/index. htm, n.d., retrieved 15 August 2012 and Departemen Agama, Al-Qur'an dan Terjemabnya (Semarang: Toha Putra, 1989), p. 123.

2 See for example Syaikh Muhammad bin Umar Nawawi, Syarh `Uqud 'l-hijjayn fi Bayāni Huqūqiz Zawrayn (Jeddah and Indonesia: Sanqofurah, n.d); Mahmud Muhammad Jauhari and Muhammad Abdul Hakim Khayyal, Membangun Keluarga Qur'ani: Panduan untuk Wanita Muslimah, trans. Kamran As`ad Irsyady, Mufliha Wijayati, (Jakarta: Amzah, 2000). 
The above religious and state law construction is ideal, but if all men can give economic support for the family especially because at certain time, women have reproductive burdens such as being pregnant, giving birth and breast feeding. It is unjust for women if during this period, they are given extra burden of providing economic support for the family. However, in reality, not all men are capable of economically supporting their family and not all women are incapable of economically supporting their family. In this situation, the existing construction can have negative implication on women. The belief that men are the leaders and the family breadwinners often makes many Muslims blind to the reality that there are some men who are unable to earn living, but they are still being seen as family breadwinners. On the other hand, many Muslims also seem not to realize that in reality, there are many women who can be superior to men in their level of education and income, and therefore women can economically support their family. However, due to the existing assumption, women are often mainly seen as housewives. Therefore, even though women are busy with their income generating activities, at home, women are still expected to do housework, taking care of the children and serving their husband. This relationship puts more burdens for women (by earning money, doing housework, taking care of the children and serving their husband), leaving men with no responsibility while receiving their rights to be recognized as the family leader. Ideally, if the wife earns living to support the family, the husband who, for instance cannot do the same, should also be flexible in his role by taking over domestic works.

Furthermore, based on literal interpretation of the Qur'anic verse 4: 34, women are instructed to be obedient to their husband. Nusyü, which is often interpreted as disobedience to husband, such as rejecting to sleep with the husband or to go out without his permission, can result in women being beaten, even though it is suggested that the beating should be light and not to hurt, as the punishment for their ill-conduct. ${ }^{3}$

${ }^{3}$ Syaikh Muhammad bin Umar Nawawi, Syarh 'Uqud 'llujjayn. 


\section{The Religious Construction that Wife Should Fulfill Her Husband's Sexual Needs}

The following hadith has often been used to emphasize the importance of women's obedience to serve sexual needs of their husband:

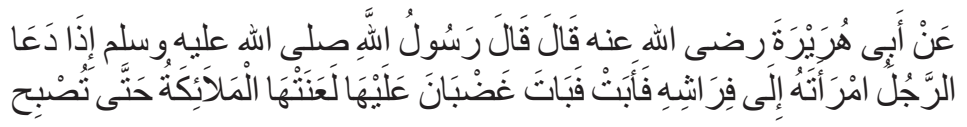

Abu Hurairah said that the Prophet said: if a husband invites his wife to his bed [to have intimate relations] and the wife refuses, making the husband angry with her all night, then the wife will be cursed by angels until morning (Bukhari, Muslim and Abū Dāwūd). ${ }^{4}$

According to Abdul Kodir, ${ }^{5}$ the majority of ulama consider this hadith as sabih h, at least in terms of the chain of narration (sanad). Ibn Hajar al-'Asqalani (772-852) is one of the ulama who argues that this hadith is sound confirmed by several other hadiths with similar meaning such as:

By the One who controls my life, (when) a person calls his wife to bed (for intimacy) and the wife refuses him, all that in the heavens will curse the wife until the husband forgives her.

The following hadith is similarly often cited to stress wife's obedience to serve the sexual needs of her husband:

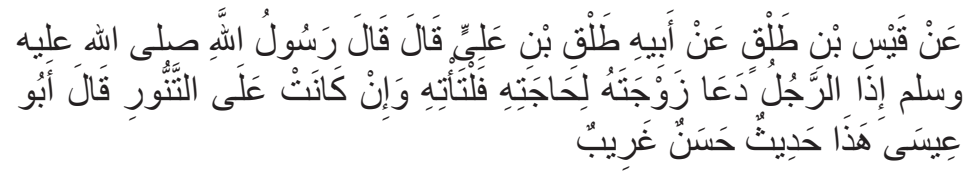

From Qais bin Talqin, from his father Țalqin bin Ali who said that the Phophet said: if a man invites his wife to fulfill his need, the wife must comply even if she is in the kitchen; according to $A b \bar{u}{ }^{\top}{ }^{\mathrm{I}} \mathrm{sa}$, this hadith

${ }^{4}$ According to Abdul Kodir, this hadith is contained in Bukhari, hadith no. 3273, Book 59, Chapter 7 and also as ḥadith no. 5248, Book 67, Chapter 86. This ḥadith is also narrated by Muslim, Abū Dāwūd, and Ạ̣mad bin Hanbal. Qibtiyah also writes that this hadith is in Ahmad bin Hanbal's collection hadith no. 9294 and Shabih Muslim no. 2594 with slight different version of narration. See Alimatul Qibtiyah, "Intervensi Malaikat dalam Hubungan Seksual”, in Hamim Ilyas et. al. (eds.), Perempuan Tertindas? Kajian Hadis-Hadis "Misoginis" (Yogyakarta: eLSAQ Press and the Center for Women's Studies, 2003), pp. 210-1. This can also be accessed in http://alimatulq.multiply.com/ journal/item $/ 7$.

${ }^{5}$ Faqihuddin Abdul Kodir, Hadith and Gender Justice. Understanding the Prophetic Traditions (Cirebon: the Fahmina Institute, 2007), p. 69. 
is hasan gharib. ${ }^{6}$

The interpretation of the above hadiths which tends to emphasize women's submission and obedience to fulfill their husband's sexual needs have been influential upon many Indonesian Muslim women. As a result, they are afraid of refusing to have a sex whenever their husband ask to do so regardless whether or not they are in the mood. Refusing to have sex is even considered to be sinful for many Muslim women.

\section{Religious Construction that Wife Should Obey Her Husband and Stay at Home}

Obedience to husband is also constructed and promoted through a famous story of a Muslim woman in the Prophet Muhammad's era. The woman was reportedly left by her husband who went to a battle and was instructed not to leave the house until he returned. Someone came to her house and told her that her father was sick. She decided not to visit him because she wanted to obey her husband's instruction not to leave the house. Even though she was sad, and desperately wanted to visit her father's house, she did not go out from the house, even when she was told that her father passed away. After the husband returned home, this case was reported to the Prophet. The Prophet was reportedly said to the woman, "because of your sacrifice, your father enters paradise". ?

Other than emphasizing women to be obedient to their husband, the existing discourse also tends to domesticate women, by referring, for example, to the hadith which encourages women to pray at home:

It is related by the wife of Abi Hamid al-Sa'di that once she met the Prophet and said, "O Prophet, I take great pleasure in praying with you." But the Prophet answered: "I know that you are fond of praying together with me. But it is better that you perform your prayers in your bedroom than in your sitting room. It is better to perform your prayers in your sitting room than in your house. It is better to perform your prayer in your house than in the neighborhood mosque. It is better to perform your prayers in the neighborhood mosque than in my mosque...".

${ }^{6}$ According to Abdul Kodir, this hadith is in Tirmidhi, no. 1193, Book 8, Chapter 10; see also Ibn al-Athir, Jàmi al-Ușül, vol. VII, no. 4707, p. 323.

7 Masdar F Mas'udi, Islam dan hak-hak reproduksi Perempuan. Dialog Fiqh Pemberdayaan (Bandung: Mizan, 1997), pp. 70-73.

8 Al-Haythami cited in Abdul Kodir, Hadith and Gender Justice, pp. 13-4. 
Domestication of women, the emphasis on the importance of wife's obedience to the husband, is also promoted through the famous and influential book studied in many pesantrens (Islamic boarding schools) of Nahdlatul Ulama (NU) like Syarb 'Uqud al-Lujjayn written by Nawawi (d. 1897). In this book, written in Arabic, it is described that a wife is like a powerless slave who should be obedient and submissive to her husband. A wife is expected to do housework, protect the dignity and the secret of her own and her husband, preserve her husband's wealth, be shy in front of her husband and never to challenge him, bow and to avoid eye contact with her husband, to be silent when her husband speaks, stand up and show respect when her husband approaches her, and do her best to please and satisfy her husband.

In addition, the idea of women's submission to husband is constructed in many other publications, some of which are translated from Arabic. For example, Membangun Keluarga Qur'ani: Panduan untuk Wanita Muslimah was a translation of Egyptian work. This book goes against Western feminism, and therefore argues for polygamy and women's submission to their husband. In this book, polygamy is seen as "solution" to women's problem of being single and a "good deed" for married women to allow their husband to marry a single woman, because this will allow the single woman to gain sexual satisfaction and protect her dignity. This book also emphasizes husband's role as the leader of women, and therefore wife's obedience to her husband is a must. Disobedience is prohibited and can cause women to be punished in this world and hereafter. The status of a wife, according to Jauhari and Khayyal, the writers of this book, is like the status of a daughter in relation to her father. But the husband has even more right over his wife based on the hadith: "If I can allow someone to take a bow other than to God, I will instruct a woman to take a bow to her husband".?

Furthermore, Mia Siti Aminah, in her book Muslimah Career: Mencapai Karir Tertinggi di Hadapan Allah, Keluarga dan Pekerjaan also encourages women to stay at home, emphasizing women's roles as wife and mother and stressing the importance of asking the husband's

\footnotetext{
${ }^{9}$ Jauhari and Khayyal, Membangun Keluarga Qur'ani, pp. 133; 195-6.
} 
permission to go out from home. ${ }^{10}$ However, this book seems to be ambiguous. The writer, on the other hand, seems to encourage women to stay at home and not to work without her husband's permission. But, in another part of the book, the writer suggests that when the wife works outside the house, the husband should do housework and not to see it just as female duties. ${ }^{11}$

The construction of women to stay at home and be submissive to their husband is promoted through weekly religious meeting (pengajian) in mosques. In two weekly religious meetings that I attended in my neighbourhood, two different female preachers, for example, suggested to accept and be grateful to whatever amount of money the husband bring home and this amount, no matter how small, is suggested not to reduce the wife's service to husband, assuming all the husbands can give maintenance to the wife. Another preacher, quoted a hadith which states when woman serves food, she should provide whip for her husband to hit her if the food is not delicious.

The above description shows how the majority of Indonesian Muslims, male and female, have uncritically used the Qur'an and hadiths to justify women's subordination, domestication and submission to their husband. As part of Indonesian Muslim communities, I myself had been taught and become part of that majority until nearly end of the 1990s. I believed that women are subordinate to men, and therfore should obey husband, and that the perfect place for women is at home.

However, since the early 1990s, when the influence of Muslim feminists began to come to Indonesia, ${ }^{12}$ there have been some efforts conducted by Indonesian Muslim feminists especially among young NU circles to teach how to read the Qur'an and hadiths critically. They argue that the coming of Islam aimed at elevating and advancing the position of women, who were subordinated in the pre-Islamic era. Therefore, they argue that the Qur'an and hadiths cannot be used to justify women's subordination. The following part of the paper elaborates Indonesian

${ }^{10}$ Mia Siti Aminah, Muslimah Career: Mencapai Karir Tertinggi di Hadapan Allah, Keluarga dan Pekerjaan (Yogyakarta: Pustaka Grhatama, 2010).

${ }^{11}$ Ibid., p. 45.

${ }^{12}$ Nina Nurmila, "The Influence of Muslim Global Feminism on Indonesian Muslim Feminist Discourse," Al-Jami ab: Journal of Islamic Studies, Vol. 49, No. 1, 2011, pp. 33-64. 
Muslim feminists' challenge to the existing construction of husbandwife relationship by offering other alternative reading of the Qur'an and badith from equal gender perspective.

\section{Indonesian Muslim Feminists' Reconstruction of Husband- Wife Relationship}

Beginning the late 1990s, there has been increasing number of Indonesian Muslim feminist publications which challenge the existing discourse of the relationship between men and women. These Muslim feminists argue that (a) men are not naturally the leaders of women; (b) women have the same right to sexual relationship; (c) home is not necessarily the best place for women. Overall, they argue for equal partnership between husband and wife. These arguments will be elaborated in this part of the paper.

\section{Men are not Naturally the Leader of Women}

The argument that men are not naturally the leader of women is elaborated in Nasaruddin Umar's book. ${ }^{13}$ In this book, Nasaruddin Umar, the current Deputy Minister for Religious Affairs, differentiates between the use of the word untha and dhakar in contrast to the word rijal, nisa' and mar'ah in the Qur'an. He argues that the Qur'an uses the word untha (female) and dhakar (male) to refer to sex or biological differences between men and women, and the Qur'an uses rijaal, nisa' and mar 'ab to refer to gender. Rijal, according to Umar, is the person, either male or female, who has certain qualities. ${ }^{14}$ Based on this differentiation, Umar argues that leadership should not be based on sex (male/dhakar), but on the fulfillment of certain requirements. ${ }^{15}$ The requirements of being leader of the family are stated in the Qur'an sura an-Nisa' (4): 34. In this verse, the rijalis the leader because (1) he/she has superiority over his/her spouse [this superiority can be in the level of education and income] and (2) that he/she spends his/her income to support the family. Whoever this person, either male (dhakar) or female (untha), can be the leader

${ }^{13}$ Nasaruddin Umar, Argumen Kesetaraan Jender: Perspektif Al-Qur'an (Jakarta: Paramadina, 1999).

${ }^{14}$ Ibid., p. 153.

${ }^{15}$ Ibid., p. 149-50. 
(qawwam) of the family because being the rijaal should be achieved, not naturally be given. Not all males (dhakar) can fulfill the above two criteria [to be qawwam] stated in the Qur'an, and not all females are incapable of fulfilling these two criteria.

The argument that men are not necessarily the leader of women has also been elaborated by Kiai Husein Muhammad (KHM), one of the National Commissioners for Women and the leader of Pesantren Darut Tawhid Arjawinangun. He argues that the Qur'anic verse 4: 34 is informative verse, not normative verse. ${ }^{16}$ This means that the verse informs gender relation [husband-wife relationship] at the time of revelation. This gender relation at the time of revelation [that men are leader for women] can be the same with or different from gender relation in the current context. In the current context, men and women can be equal partner or women can be the leader of men. However, the majority of Muslims generally understand this verse as normative verse, intepreted as norm for all Muslims anywhere and anytime to appoint men as leader of the family, regardless whether or not men have certain qualities stated in the Qur'an (4:34) above.

The above KHM's argument is similar to the argument of two other Muslim feminists and reformists from India and Egypt respectively: The late Asghar Ali Engineer (10 March 1939-14 May 2013) and Nasr Hamid Abū Zayd (10 July 1943-5 July 2010). Asghar Ali Engineer argues that Qur'an verse 4: 34 is sociological verse, not theological verse; or contextual verse, not normative verse. Sociological verse means that the verse tells the sociological description of gender relation (husband-wife relationship) at the time of revelation, which may be the same or different from gender relation in the current context. Theological verse means normative verse which should be applicable to all Muslims anywhere and anytime. ${ }^{17}$ Engineer further clarifies his argument that the verse reflects the social situation at the time of revelation, according to which men were qawwam, but does not declare any sign of norm. ${ }^{18}$

Similarly, Nasr Hamid Abū Zaid argues that Qur'an verse 4: 34 is

${ }^{16}$ Husein Muhammad, Ijtihad Kyai Husein: Upaya Membangun Keadilan Gender (Jakarta: Rahima, 2011). 1992).

17 Asghar Ali Engineer, The Rights of Women in Islam (London: C. Hurst \& co., 18 Ibid., pp. 45-6. 
descriptive, not prescriptive verse. This means that Qur'an verse 4: 34 describes gender relation at the time of revelation, not the verse which prescribes gender relation for any Muslims regardless of time and space. ${ }^{19}$ As stated earlier that the gender relation described in the Qur'an verse 4: 34 is ideal and just, if the men can give economic support for the family.

\section{Women Have the Same Right to Sexual Relationship}

Efforts to counter the existing discourse of the relationship between husband and wife were also undertaken by Perhimpunan Pengembangan Pesantren dan Masyarakat/P3M [the Association of the Development of Islamic Boarding School and Society), which was founded on 18 May 1983. P3M was among the pioneers of the association which puts pesantren as the center of excellent for community development. In the 1990s, when P3M was under the leadership of Masdar F Mas'udi, it has Figh an-Nisa' [Islamic jurisprudence on women] division, which gives information and training on women's reproductive rights in the pesantrens. It was based on the need of the training participants in the pesantrens, Mas'udi wrote the book on women's reproductive rights.

In his book, Mas'udi argues againts the existing discourse of husband-wife relationship by emphasizing women's reproductive rights. ${ }^{20}$ These reproductive rights are the women's rights: (1) to choose their marriage partner which contradicts the tradition of forced/arranged marriage; (2) to enjoy sexual relationship which opposes the existing emphasis on women's obligation to serve their husband's sexual needs; (3) to have children which opposes the existing demand/obligation for women to bear children after marriage; (4) to decide when and how many pregnancies women could have which goes againtst the existing control of a husband over his wife's body, often in the form of prohibiting the use of contraception; (5) to take care of their children which disagrees with the existing emphasis of women's obligation to take care of their children or to emphasize the women's rights over the custody of their children in the case of divorce; (6) to have reproductive leave such as not having obligation to pray during their menstruation and parturition

19 Nasr Hamid Abū Zayd, "The Nexus of Theory and Practice", in Mehran Kamrava (ed.), The New Voices of Islam: Rethinking Politics and Modernity (Berkeley and Los Angeles: University of California Press, 2006), pp. 163-4.

${ }^{20}$ Masdar F. Mas'udi, Islam dan Hak-hak. 
and not having a sex with their husband which opposes the belief that women are lack of reason and religion because they do not pray during these two periods; and (7) to divorce their husband which opposes against the existing belief that only men can divorce their wives.

Mas'udi's book empowers women especially in changing women's perception on their sexual relationship with their husband: from seeing sexual activities as obligation to right. When women see this sexual relationship as obligation, the focus is only one: the fulfillment of the male sexual desire. On the other hand, when women see this sexual relationship as right, this means they have the right to ask the husband to fulfill her sexual desire and can say no to their husband, such as when they are sick or very tired. But how about hadith on the curse of the angel to women who refuse to sleep with their husband?

Alimatul Qibtiyah's article provides alternative reading by using language and usül al-fiqh [methodology of Islamic jurisprudence] analysis to the following hadith:

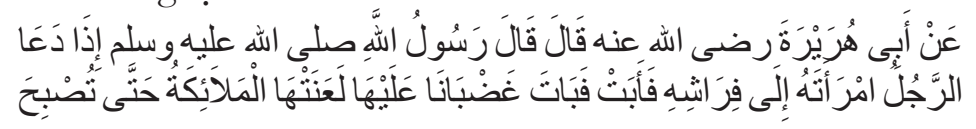

In terms of language, the hadith uses the word "da'a,", which means "to invite in a good manner" and the word "aba,", which means "to reject in a rude manner". This means, the translation of the hadith should be: "when a husband invites his wife to have a sex in a good manner but the wife rejects his invitation in a rude manner, [in another version, there is additional phrase "and this causes the husband to be angry"], the angel will curse the wife until dawn." Is it possible for the angel, the God's creature which was created from the light and is reported not to have willingness to disobey God, to curse the women? Qibtiyah suggests that the curse of the angel should be interpreted metaphorically as "uncomfortable situation between wife and husband" as a result of the wife's rude rejection. ${ }^{21}$ To invite our spouse to have a sex is a very sensitive act and may be embarrassing for someone who has done this in a good manner, so that the rejection in a rude manner might lead to mental discomfort.

Furthermore, Qibtiyah uses one of the principles of Islamic jurisprudence, which means that "the law applies to others not stated

${ }^{21}$ Alimatul Qibtiyah, "Intervensi Malaikat". 
in the text but have similar reasons/characteristics, and this can be understood from the context of the language." The hadith therefore can also be understood that: "If the wife invites the husband to have sex in a good manner but the husband rejects her invitation in a rude manner, [if we insert additional phrase as stated in another version: "and this causes the wife to be angry"], the angel will curse the husband until dawn." 22

This alternative reading of the hadith is useful for the wife who at certain times may not be willing to have sex, but is afraid to say no to her husband. By reading this hadith differently, one may say that it is acceptable to say no or to postpone having sex in a good manner. This understanding is in accordance with the Qur'anic instruction stated in Chapter 4: 19 that husband should treat his wife well. The Qur'an Chapter 2: 187 also states that in terms of sexual relationship, the wife is like a cloth to her husband and vice versa, which means that both husband and wife need each other. Both of them ideally should understand each other in trying to fulfill each other's needs.

In addition to Mas'udi and Qibtiyah, Syafiq Hasyim, who joined P3M since 1996 and became the staff of Fiqh an-Nisa' division also wrote a book as his reflection of his experiences in organising the women's reproductive trainings, Hal-hal yang Tak Terpikirkan tentang Isu-isu Keperempuanan dalam Islam. Sebuah Dokumentasi. ${ }^{23}$ In this book, he shows that Islam came to advance women's rights. But misogynistic and patriarchal readings of the Islamic texts have contributed to women's subordination. He emphasizes the importance of deconstructing the existing patriarchal figh such as to redefine marriage, deconstruct the concept of guardianship (wali) in marriage, and reinterpret the concept of polygamy, divorce (thalaq), and waiting period (iddah). He also calls for the production of new figh which empowers women.

However, disappointed by Mas'udi's practice of polygamy in the late 1990s, many staff members of P3M, such as Lies Marcos-Natsir, Farhah Ciciek, and Maman Abdurrahman, left P3M and formed their own institution: Rahima, the Centre for Education and Information on Islam and Women's Rights, in Jakarta, and the Fahmina Institute, a non-

${ }^{22}$ Ibid.

23 Syafiq Hasyim, Hal-halyang Tak Terpikirkan tentang Isu-isu Keperempuanan dalam Islam: Sebuah Dokumentasi (Bandung: Mizan, 2001). 
government organization (NGO) which aims at promoting social and gender justice in Cirebon in 2000. Other than these two institutions, Sinta Nuriah, the first lady of the former president Gus Dur who took her master's studies at the Women's Studies Program at Universitas Indonesia and did her thesis on early marriage and women's reproductive rights, also formed Forum Kajian Kitab Kuning/FK3 [The Forum for the Study of 'Yellow Book') in $1997^{24}$ and Puan Amal Hayati established Pesantren untuk Pemberdayaan Perempuan dan Anak [Islamic Boarding School to Empower Women and Children] in 2000. Both are based in Jakarta.

Knowing how influential 'Uqud al-Lujjayn is on many pesantren alumni, the Forum has written Wajah Baru Relasi Suami Istri: Telaah Kitab 'Uqud al-Luijayn [The New Version of Husband-Wife Relationship: Critical Analysis of the Book of 'Uqud al-Luijayn] in 2001 '25 and Kembang Setaman Perkawinan: Analisis Kritis Kitab 'Uqud Al- Lujjayn in $2005^{26}$ with the aim of countering the existing unjust husband-wife relationship. Furthermore, to counter the influence of Uqud al-Lujjayn, Faqihuddin Abdul Kodir from the Fahmina Institute also wrote Mamba'us Sa'adah [Sources of Happiness] advocating the principles of good relationship between husband and wife. ${ }^{27}$ This book is written in Arabic printed in yellow paper to gain acceptance in many pesantrens. In addition, the book also contains sixty hadiths on gender equality to support the advocacy of women's rights. One of the reasons for adding these hadiths is to argue againts the hadiths commonly mentioned to justify the subordination and domestication women.

As an expert of ḥadith, Abdul Kodir has also previously written Hadith and Gender Justice: Undertanding the Prophetic Traditions ${ }^{28}$ in which he calls for critical reading of the content (matan) and the chain of

24 “Sinta Nuriyah Abdurrahman Wahid", Kompas, at http://bukantokohindonesia.blogspot.com/2009/06/sinta-nuriyah-abdurrahman-wahid.html, Minggu 8 Mei 2005, retrieved 28 August 2012.

${ }^{25}$ Forum Kajian Kitab Kuning (FK3), Wajah Baru Relasi Suami Istri: Telaah Kitab Uqud al-Lujjayn (Yogyakarta: LKiS Yogyakarta in cooperation with The Ford Foundation dan FK3, 2001).

${ }^{26}$ Forum Kajian Kitab Kuning (FK3), Kembang Setaman Perkawinan: Analisis Kritis Kitab 'Uqud Al- Lujjayn' (Jakarta: Kompas, 2005).

${ }^{27}$ Faqihuddin Abdul Kodir, Mamba'us Sa'adah (Cirebon: Institut Studi Islam Fahmina, 2012).

28 Abdul Kodir, Hadith and Gender Justice. 
transmission (sanad) of some ḥadiths. For example, he quotes Al-Ghazali who criticizes the argument that the content of the above hadith which encourages women to pray at home is incompatible with the historical fact that the Prophet's wives and his female companions joined his congregational prayers. In fact, special entrance to the mosque was provided for women. And it is reported that when the Prophet heard a crying baby during his congregational prayer, he shortened his prayer to give the mother and her baby time to calm them down. In another hadith, it is reported that the Prophet asked not to prevent women from entering the mosque, contradicting the hadith which encourages women to pray at home. ${ }^{29}$

On sexuality, Abdul Kodir found another version of hadith which provides alternative understanding on the emphasis of women's submission to the husband, according to Tirmidhi's transmission. In the transmission of Imam Aḥmad (Musnad, ḥadith no. 16545), the word used in the hadith is "falya'tiha", while in Tirmidhi's transmission "falta'tibi" 30

الله عليه وسلم إِذَا أَرَادَ

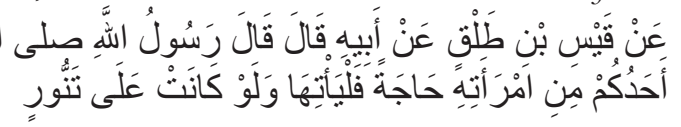

This different version of the hadith can read to different translation. The translation of Tirmidhi's transmission is: "Your wife should come to you when you wish to fulfill your biological needs, even when she is in the kitchen; while the translation of Imam Ahmad's version is "If you wish to fulfill your biological needs with your wife, come to your wife, even when she is in the kitchen." This can be interpreted that the husband can only fulfill his sexual needs with his wife, even when the wife is in the kitchen. He should go to where the wife is to invite her politely. The difference version of Tirmidhi's transmission, falta'tibi, and Imām Aḥmad's version of falya'tiba, according to Abdul Kodir, ${ }^{31}$ on the ground of the science of hadith, is considered a serious discrepancy that can reduce the validity of the hadith into the level of weak (dho if ${ }^{\circ}$ hadith.

${ }^{29}$ Ibid., p.14.

${ }^{30}$ Ibid., p.74.

${ }^{31}$ Ibid. 


\section{Home is not Necessarily the Best Place for Women}

Mas'udi also calls for critical reading of the content and the validity of the hadith. For instance, in response to the famous " hadith" of a woman who did not visit her father for obeying her husband to stay at home, Mas'udi calls for scrutinizing whether that story is hadith. In addition, he argues that even when the woman decided to leave the house and visited her father when her husband was away, the Prophet might not blame what she did. The Prophet is a wise person, who must know that the woman was still mourning. If he was not a wise person, he might have blamed the woman for what she did, but he did not. Instead, the Prophet seems to entertain the woman that because of what she did, promising that her father enters paradise. Furthermore, in response to the hadith which is commonly used to domesticate women, and put women under the full authority of their husband, Mas'udi quoted some ulama (Muslim scholars) who argue that it is reprehensible for a husband to forbid his wife to visit her ill parents. Abū Hanifah, according to Mas'udi, allows a wife to leave the house to visit her ill parents without her husband's permission. ${ }^{32}$

In addition, if the above narration is valid, the husband asked the wife to stay at home due perhaps to his love and was worried about her safety during the war time. In the context of war, home might be the safe place for woman. However, Indonesian current situation is different from the context of war in the early period of Islam. In fact, it is safe for women to go out from home to work, study, or visit their parents.

\section{Conclusion}

The discourse of husband-wife relationship in Indonesia mainly centered at the patriarchal construction of the asymmetrical relationship between men and women. Men are constructed to be the leaders of women. Women are commanded to be obedient and submissive to their husband and instructed to stay at home and only go out with their husband's permission. Religion plays an important role in this construction. Religious texts have often been used and interpreted in order to justify patriarchal construction of the relationship between husband and wife. For example, Indonesian Muslims mostly interpret the

${ }^{32}$ Masdar F. Mas'udi, Islam dan Hak-bak, p. 72. 
Qur'anic verse 4: 34 to mean that men are naturally leaders of women. Some of them may use the verse to prevent women from becoming leader. In addition, using some hadiths, many Muslims believe that it is women's duties to obey, submit, and fulfill sexual needs of the husband. Using the " hadith" which prescribes women's obedience to their husband, Indonesian women are prohibited to go out without their husband's permission, even for visiting sick parent.

Most Indonesian Muslims, both men and women, have taken for granted the above asymmetrical construction of the relationship between men and women. However, since the coming influence of Muslim feminism, there has been increasing number of emerging Muslim feminists who challenge this asymmetrical relationship. These Muslims feminists, as discussed earlier in this article, have offered other alternative reading to religious texts of Qur'an and hadith seen from equal gender perspective. They argue that men are not born as leaders, but should have certain qualifications to achieve leadership. By the same token, a woman who has the same qualifications of leadership can be a leader. In addition, the Muslim feminists also argue that both husband and wife have the same right to enjoy sex, and it is acceptable for women to initiate sexual relationship, or to reject it in a polite way when they are not ready. Furthermore, Muslim feminists also argue that home is not necessarily the best place for women to spend their time. Their life would be beneficial for others if women can go out to study, teach, or work for the economic benefit of their family. Overall, Muslim feminists argue for equal partnership between husband and wife and reject women's subordination. 


\section{BIBLIOGRAPHY}

Abdul Kodir, Faqihuddin, Hadith and Gender Justice. Understanding the Prophetic Traditions, Cirebon: the Fahmina Institute, 2007.

----, Mamba'us Sa'adah, Cirebon: Institut Studi Islam Fahmina, 2012.

Abū Zayd, Nasr Hamid, “The Nexus of Theory and Practice”, in Mehran Kamrava (ed.), The New Voices of Islam: Rethinking Politics and Modernity, Berkeley and Los Angeles: University of California Press, 2006.

Aminah, Mia Siti, Muslimah Career: Mencapai Karir Tertinggi di Hadapan Allah, Keluarga dan Pekerjaan, Yogyakarta: Pustaka Grhatama, 2010.

Departemen Agama, Al-Qur'an dan Terjemahnya, Semarang: Toha Putra, 1989.

Engineer, Asghar Ali, The Rights of Women in Islam, London: C. Hurst \& co., 1992.

Forum Kajian Kitab Kuning (FK3), Wajah Baru Relasi Suami Istri: Telaah Kitab Uqud al-Lujjayn, Yogyakarta: LKiS Yogyakarta in cooperation with The Ford Foundation dan FK3, 2001.

----, Kembang Setaman Perkawinan: Analisis Kritis Kitab 'Uqud Al- Lujayn', Jakarta: Kompas, 2005.

Hasyim, Syafiq, Hal-halyang Tak Terpikirkan tentang Isu-isu Keperempuanan dalam Islam: Sebuah Dokumentasi, Bandung: Mizan, 2001.

Jauhari, Mahmud Muhammad and Muhammad Abdul Hakim Khayyal, Membangun Keluarga Qur'ani: Panduan untuk. Wanita Muslimah, trans. Kamran As`ad Irsyady, Mufliha Wijayati, Jakarta: Amzah, 2000.

Mas'udi, Masdar F, Islam dan Hak-hak Reproduksi Perempuan: Dialog Fiqh Pemberdayaan, Bandung: Mizan, 1997.

Muhammad, Husein, Ijtihad Kyai Husein: Upaya Membangun Keadilan Gender, Jakarta: Rahima, 2011.

Nawawi, Syaikh Muhammad ibn Umar, Syarh 'Uqüd al-Lujjayn fi Bayān Huqüqz, Zawrayn, Jeddah and Indonesia: Sanqafurah, n.d.

Nurmila, Nina, "The Influence of Muslim Global Feminism on Indonesian Muslim Feminist Discourse," Al-Jami ah: Journal of Islamic Studies, Vol. 49, No. 1, 2011, pp.33-64. 
Qibtiyah, Alimatul, "Intervensi Malaikat dalam Hubungan Seksual, in Hamim Ilyas (eds.), Perempuan Tertindas? Kajian Hadis-Hadis "Misoginis", Yogyakarta: eLSAQ Press and the Center for Women's Studies, 2003.

Umar, Nasaruddin, Argumen Kesetaraan Jender: Perspektif Al-Qur'an, Jakarta: Paramadina, 1999. 